\title{
Uma vida em segredo: o livro e o filme
}

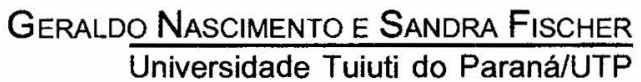




\section{Resumo}

Este artigo parte de uma reflexão sobre linguagens. Trata-se de um trabalho de pesquisa, ainda em construção, que reúne a leitura de duas versões da mesma história, uma literária e outra filmica: Uma vida em segredo, novela de Autran Dourado, e filme homônimo de Suzana Amaral.

\section{Palavras-chave}

comunicação; linguagens; novela; filme; Uma vida em segredo

\section{Abstract}

This article derives from a reflection on language. It is part of a major work, still in process; presents an analysis of two versions of the same story: Uma vida em segredo, novel written by Autran Dourado and film directed by Suzana Amaral.

\section{Key words}

communication; language; novel; film; Uma vida em segredo 
s versões literária e filmica de Uma vida em segredo, não
obstante tratarem do que poderíamos chamar de úm mesmo
esquema narrativo; suscitam questões peculiares, decorrentes não só do ponto de vista de Autran Dourado (livro) e de Suzana Amaral (filme), mas sobretudo das linguagens que cada um dos artistas convoca. Destacamos do livro, em nosso artigo, a noção de segredo, vinculada ao plano de expressão e, mais de perto, à materialidade da palavra; do filme, procuramos alinhavar pontos constituintes das relações identitárias da personagem a partir, basicamente, da estruturação imagética que a manifesta.

\section{Do livro}

Segredo tem um póuco de enigma, e enigma é algo que se oferece à decifração: algo que "não parece, mas é", intriga. Uma vida, a de Biela, a protagonista? Com certeza.

Biela (duas ela?). O nome, acreditamos, pode ser considerado como uma espécie de máscara da identidade; poderia revelar - ou falsear - as identificações do sujeito manifestas em suas escolhas, em seus modos de ser e de viver? Este o nosso ponto de partida.

Há nas palavras uma espécie de vida, de vida em sègredo. Quando nos deparamos com Uma vida em segredo, de Autran Dourado, em cuja leitura encontramos algo assim como um incômodo meio intraduzível, assim quase da ordem do indizível, do estranho. Um visto nunca visto, um vislumbre talvez. Sabe-se lá o quê.

De imediato, todavia, pareceu-nos que no texto de Dourado havia algo que não fechava, que não se encaixava. Um desencaixe. Alguma coisa que, se não se revelava em ser, também não se esvaía 
em nada, num não ser apaziguador. Ao contrário. Insistia em permanecer, resto insistente de um objeto nunca dantes sequer vislumbrado, quanto mais perdido. Sempre a mesma história de uma certa Biela, prima Biela, mulher-menina no início do livro, já ali começando a entrar em anos. Órfã, matuta, desajeitada. A mãe desde cedo perdida, criada pelo pai. Morto este, Biela só. Trazida para a cidade lá dos confins da Fazenda do Fundão, por idéia de prima Constança. Constança, prima por laço de lei, mulher de Conrado que era, este sim, primo de Biela por laço de sangue. Incitado então por Constança, Conrado vai buscar Biela para viver com os primos, e assim foi que ela chegou montada no lombo de um cavalo seu, cavalo malhado de vermelho e branco, cavalo ronceiro, de cara branca.

A família de Conrado, toda reunida na porta e na janela à espera da novidade, desiludiu-se um pouco com aquela figura miúda e socada, encilhada no animal, debaixo de uma sombrinha vermelha. De um salto a figura se põe no chão, sem aceitar a ajuda que Conrado oferecia. Nela repararam em tudo, em tudo o que dava para ver. Em todos os detalhes da sombrinha, das botinas, da saia comprida, da blusa fechada até o pescoço. Os gestos todos, viram. Só não viram, mesmo, a cara. Porque a cara Biela mantinha sempre baixa.

$\mathrm{E}$ assim foi, na história toda. Praticamente ninguém ali viu de Biela muito mais do que isso, os gestos desarranjados, sem graça, de pouco sentido. Nem mesmo a menina Mazília, tocadora de piano, cuja música tanto viria, no enredo, a encantar, deslumbrar Biela, nem mesmo ela viu. Se por acaso viram, mais tarde, foi por pouco tempo, e trataram logo de esquecer. No começo bem que tentaram, e como. Principalmente prima Constança, que fez de um tudo para tentar acomodar e integrar Biela. Ensinou modos e modas, mostrou como se comia e como se fazia isso e mais aquilo e mais aquele outro. Fezlhe notar que era rica, fazendeira abastada vivendo longe da roça. Não carece fazer economia, o dinheiro é seu, prima Biela. Constança compra tecidos, costura vestidos e, despindo Biela dos panos velhos trazidos do mato, nela veste as roupas da cidade.

Mas Biela não se acostuma, não se conforma aos novos trajes.

Biela. Triste e sozinha, apagada e sem viço, "nenhuma graça, nenhum ritmo macio, nenhuma leveza, nada que revelasse 
naquele corpo uma alma feminina",' pensa Constança, sentindose rebaixada efendida em sua feminilidade pela presença da prima. Desengonçada demais, humilde demais, caipira demais. Boazinha, tão boazinha que até parecia tonta. Sonhando acordada, imersa em brumas que do passado lhe trazem a figura materna truncada, sem rosto. Calada, ensimesmada, apática. Cordata. Ou nem tanto.

Porque afinal, lá pelas tantas, inesperadamente emerge: surge recomposta, incisiva, quase violenta, dona de uma força insuspeitada. Postada em frente ao espelho, desmontada após frustrada tentativa de noivado e casamento - burrice com a qual concordara, sim, mas devido às insistências dos parentes - em revolta arranca os trajes que Constança lhe impingira. E eis que ela, então, Biela - duas ela? -, aparentemente tão sem vida, de seu jeito, quase em silêncio, assim tramando por dentro e costurando por fora, acaba fazendo na história aquilo que é de sua vontade e decisão, tecendo um tecido todo seu. Pano esgarçado e com brechas, percebe-se. Mas seu.

Retoma as vestes antigas, de chita, o xale herdado da mãe, as roupas de roça e de fazenda. À revelia dos primos, abandona sala e mesa da família; passa a viver na cozinha, junto aos empregados, proseando, com eles comendo, como eles trabalhando, hábil. Toma posse do pilão - resquício de sua vida outra, de um tempo em que aprendera a aliviar a bexiga em pé, feito homem - e começa, no tempo da nova vida, a socar: "Pilava milho, torrava e moía café, debulhava amendoim, catava arroz, descascava batatas". ${ }^{2}$ Ágil, movimenta-se desenvolta em andanças pela cidade, desacompanhada, visitando quem bem entende. Por vezes ajudando no serviço doméstico, em cozinhas alheias, recebe pequenas pagas pelos préstimos. Passa a dormir no quarto dos fundos, perto da despensa. Sob a cama, o tesouro das moedas amealhadas. De noite, brinca com elas, feito fossem seixos rolados do riachinho, vindos do Fundão.

Em seus passeios, errante, Biela gasta horas admirando a lida do ferreiro Borromeu a ferrar cavalos: brasas, fagulhas do fole, "o malho no ferro vermelho sobre a bigorna", ${ }^{3}$ estrelinhas

1 Dourado, 1996, p. 56.

2 Dourado, 1996, p.126.

3 Dourado, 1996, p.133. 
voando. Certa feita, voltando pra casa, o encontro: seguindo-lhe as pegadas, um cachorro. Triste cachorro perdido, tão Biela quanto ela. Cachorro sem dono, sem nome. Titubeantes, negaceando, acertam o passo. Juntam-se, os dois. E, num vislumbre, Biela lhe dá nome: Vismundo. Epifania?

Uma vida em segredo. Segredo tem um pouco de enigma, e enigma é algo que se oferece à decifração. Mas foi somente quando o advento do filme Uma vida em segredo, da cineasta Suzana Amaral, novamente nos conduziu às malhas do texto literário, que nos ocorreu entremear à trama da análise os fios das leituras dos textos de Lacan ${ }^{4}$, por uma lado, e da semiótica greimasiana, por outro. E então cismamos que talvez - quem sabe? - a origem do enigma pudesse estar no significante, na letra.

O nome da letra? Erre. Talvez pudesse ser o Erre. A letra, mesmo, assim: R. Porque desde o princípio intriga, em Biela, o sumiço do $\mathrm{R}$, desaparecido do codinome escolhido para a protagonista, de nome Gabriela. Privada do travo vibrante do encontro consonantal, Gabriela não fibrila: sobra a palavra infantilizada, abebezada, Gabiela; cindida, é reduzida a Biela - simplificada, fácil de falar, apenas a amenidade do encontro vocálico. A sedução provocada pela presença da falta, nos fez errar por Uma vida em segredo, em busca do Erre perdido.

E ele aparecia, muitas vezes. No meio de Conrado, o nome do primo; em Gasparina, o nome da mãe; também em Gomercindo, em Milurde e nas diversas Marias, os amigos; em ferreiro Borromeu, reiterado à exaustão; e bem no meio de segredo. Uma vida - há vida? - em segredo. Mas foi só no fím desse percurso que se pôde dar conta de que o Erre aparece deslocado, metonímico, em prima Biela - forma de tratamento dispensada a Biela. Biela, a metáfora, a peça de ligação que articula todo o movimento da trama do texto: Biela, extraído de Gabriela, perde o Erre. Biela por Gabriela. Biela, "haste de aço forjado ou fundido que, articulada em suas extremidades a duas peças móveis, transmite a uma o movimento

4 Particularmente, no caso, $O$ seminário $V$ - As formaçōes do inconsciente (Lacan, 1999), "Função e campo da fala e da linguagem em psicanálise" (Lacan, 1998) e "A instância da letra no inconsciente" (Lacan, 1998) 
da outra, modificando-o ou não". ${ }^{5}$ Biela duas ela, cuja materialidade estivera lá antes mesmo de Biela ser Biela, no Erre inaugural da prima vez, no Erre de prima.

A letra, a ferro e a fogo, vibrando, criando estrelas, centelhas, fagulhas. $O$ ferreiro Borromeu.

Há uma falta em ser, em Biela, uma ausência constituinte que a coloca em movimento, em busca do objeto perdido. Um desejo. Perdida nos cacos de memória que lhe entregam ecos das lembranças da mãe, de imagens do Fundão, prima Biela deseja?

A primeira designação da protagonista da história de Autran Dourado, dada pelas palavras prima Biela, ocorre já na abertura da história: "Quem deu a idéia de trazer prima Biela para a cidade foi Constança. Deixa, Conrado, traz ela pra casa, disse. Biela fica morando com a gente ..." $\mathrm{E}$ daí por diante foi no texto sempre apenas Biela, até bem perto do fim. E o fim colheu prima Biela pouco depois do encontro com o cachorro de nome Vismundo.

No momento em que se aproximava de sua hora derradeira, Biela entrelaçou na trama os seus fios significantes, bordando no texto a marca daquilo que era, que sempre fora seu. "... assinou numa letra tremida o seu nome: Gabriela da Conceição Fernandes. " $\mathrm{O}$ objeto estilhaçado, a falta primordial e constitutiva, o fragmento do significante perdido, irrecuperável. Metonimicamente está lá, o. Erre de Gabriela.

A sideração, o vislumbre - Biela vira o mundo? - o desejo se configurando e criando o significante, a luz, a metáfora constituída pelo nomeado: Vismundo, o cachorro, metonímia do Fundão. Significados deslizando por entre fragmentos, cacos, ecos-delírio. Gabriela no espelho, trêmula, Biela se vendo refletida em Vismundo, inteira, Gabriela, calafrio, a falta outra vez, Biela de novo, abrindo o último parágrafo do texto, estilhaçada, parte:

Biela sentiu apenas um calafrio, um nojo distante. Não via bem na sua frente, as pessoas eram umas névoas

5 Houaiss \& Villar, 2001, no verbete biela.

6 Dourado, 1996, p.29.

7 . Dourado, 1996, p.160. 
leitosas, trêmulas, longes demais. Mal percebia que lhe tocavam. Sentiu vagamente que lhe passavam qualquer coisa nos lábios. O gosto do óleo e um cheiro forte penetrante de mato pisado que vinha com um vento não sabia de onde. Viu não mais com os olhos, estes estavam para ela fechados, umas manchas brancas deslizando rápidas. Um pasto muito verde onde as manchas se mudavam em figuras quase fluidas. E essas figuras pairavam sobre o verde, sustentadas em nada, contra um céu azul onde voavam pássaros em círculo. Começou a ouvir uma música de harmonium, um latido alegre de cachorro. E, num rápido instante, passaram por ela Mazilia toda vestida de branco no seu vestido de noiva, a mãe sem rosto cantando a sua cantiga. $O$ último a se fundir no azul foi Vismundo, que ainda perseguia os derradeiros pássaros do céu. (Dourado, 1996, p.162)

A partir daqui, retomamos o fio da inquietação do princípio e voltamos ao começo do livro, ao nome da história: Uma vida em segredo. Tal como foi feito com Gabriela - ou como o fez, talvez, ela própria, narcísica infanta, se auto-nomeando Biela -, retiramos de segredo o Erre, assim obtendo uma palavra cuja grafia e sonoridade remetem a algo familiar e estranho ao mesmo tempo. Ouvimos, então, que a ausência do Erre traz "segedo", e vemos que de segedo a desejo há apenas uma questão de deslocamento.

O Erre que falta em Gabriela, aparentemente, em segredo se aloja - escondendo (quem sabe?) de Biela o desejo. Ou revelando, talvez, que o desejo de Biela existe, vive em segredo. Não sabido.

\section{Do filme}

Será que cor o vestido dela?, indaga a menina Mazília, enquanto espera. Revolvè-se em expectativas, tão curiosa quanto Constança, a mãe, um pouco mais contida, para manter a elegância recatada de uma senhora da aristocracia rural mineira do início do século XX; ambas emolduradas pelo quadro da janela que dá para a 
rua. As palavras da menina constituem a fala inaugural do filme Uma vida em segredo (2002), de Suzana Amaral, baseado na obra literária homônima de Autran Dourado. É prima Biela quem está para chegar. Rica fazendeira, órfã de mãe, sempre vivera sozinha com o pai, como que escondida, distante do mundo e dos demais familiares, nos confins da fazenda do Fundão. Como seria, ela? As roupas, certamente lindas, que tons trariam? Olhos ávidos por novidades, a menina-adolescente imagina.

A expectativa de Mazília e de Constança, no entanto, não é a mesma que têm os espectadores do filme. Estes puderam acompanhar a longa e calada seqüência da viagem a cavalo, em que Conrado, marido de Constança, acompanhado de um capataz, traz para o seio de sua casa a agora também órfã de pai - Biela, sua prima consangüínea.

Reunida nas janelas à espera da novidade (em outra delas que também dava para a rua encontrava-se a criadagem), a família de Conrado - com exceção do menino, que se adiantava até a próxima esquina para ver mais longe - teve frustradas suas expectativas ao ver chegar aquela figura miúda e socada, encilhada no lombo de um cavalo, debaixo de uma sombrinha vermelha.

Sem esperar pela ajuda que o primo lhe oferece, Biela se põe no chão. Desconfortavelmente estaqueada em frente a seus observadores, que a contemplam do alto das janelas, agarra-se à sombrinha, agora fechada, e esforça-se, timidamente, por ajeitar o cabelo, a blusa, a saia desalinhada pela viagem.

A câmera, em sincronia com os olhos dos parentes - nenhum som na banda sonora - se aproxima e passeia pela sombrinha, pelas botinas gastas e empoeiradas, pela saia larga e comprida, pela blusa cerrada até o pescoço. Detém-se uns instantes em perscrutar a personagem: magra, angulosa, desprovida de quaisquer adereços, indumentária simples, quase grosseira, de um cinzento meio amarronzado, indefinido, apagado.

Nela, repararam em tudo. Os gestos toscos, desarranjados. Visível era até o movimento das palavras, encurraladas, a debateremse na garganta, buscando uma frase de cumprimento apropriada para a chegada. Só não viram o rosto, que Biela mantinha sempre baixo. 
Esta seqüência inicial funciona como uma espécie de prólogo para a narrativa filmica. Anuncia aquilo de que se vai tratar no filme: onde o ser nessa mulher que chega da sombra, que vida?

Prima Constança tentou integrar Biela à família. Destinoulhe o quarto da frente, lugar marcado na mesa, franqueou-lhe a sala, as conversas, as visitas. Mostrou como se comia, como se fazia isso e mais aquilo e mais aquele outro. Ensinou modos e modas, fez-lhe notar que era rica, fazendeira abastada agora vivendo longe da roça. Tinha posses, carecia se aprumar, reconhecer seu lugar. E, para começar, precisava vestir-se nos conformes.

Biela, por sua vez, embora com renitência, esforça-se por agradar Constança. Na impossibilidade de falar com a desenvoltura que admirava na prima, imitava-lhe os cumprimentos que fazia ao receber visitas ou nos encontros casuais com conhecidos; desajeitada, porém, papagueava em torno de frases feitas sem dar seqüência às conversas. Mas progredia. Numa ocasião, apareceu na sala de jantar para a refeição com um coque que tentava reproduzir o penteado da prima. Todos, até Mazília, que se apressou em retocar-lhe o penteado, viram no gesto um sinal de que nem tudo estava perdido, prima Biela começava a apreender. Constança não perde a oportunidade, elogia e anima a prima. Feliz por ter conseguido agradar aos primos, Biela decide não opor maiores resistências aos conselhos recebidos. Nada de chitas, decreta a senhora, ela própria embalada em panos preciosos, cuidadosamente trabalhados, que lhe delineiam - com sensual recato de babados, fitas, rendas - as formas femininas e arredondadas, condizentes com sua situação de esposa abastada, realizada.

Decepcionada que ficara com a figura desbotada e sem graça de Biela, Constança tinha se imposto como tarefa transformar a prima numa moça fina da cidade. Assim que possível, não perde tempo: combina levar Biela à loja de "seu" Gaudêncio - era necessário comprar panos para lhe reformular o guarda-roupa.

Constança naturalmente tinha muitas idéias para colocar seu projeto em prática. Estava verdadeiramente empenhada em sua missão, entusiasmada. Ela própria, sabia bem, vestia-se com elegância e bom gosto apurados: a prima certamente estava em boas mãos, iria sair-lhe à imagem e semelhança. 
A contemplar as vestes largas e despojadas que cobrem o corpo magro e anguloso de Biela, Constança sugere surás, veludos, tafetás. Ainda que objetando "Não posso, prima, não posso", Biela, fantoche relutante, deixa-se conduzir ao quarto de costura. Nesta seqüência, sob os sons de uma máquina de costura que não pára de trabalhar, entre fios e agulhas, uma Biela já destituída de suas vestes originais aparece com novas roupas sendo modeladas em seu próprio corpo. Com o auxílio da costureira, Constança vai fazendo experimentos, dispondo tecidos e guarnições sobre o manequim, duro feito um pau, apesar de vivo. No rosto contrafeito de Biela, as expressões da única manifestação a que se permite: caretas discretas, enquanto apertam-lhe o talhe esbelto, o pescoço longo e magro.

Não obstante o apuro dos vestidos, cosidos em ricos tecidos, Biela não se ajeita neles. Apertada, andava dura. Seu passo de matuta não se coadunava com a elegância das roupas, parecia mais um espantalho ambulante, um robô. E motivo de riso para as crianças, principalmente do menino, que a ridicularizava pelas costas e flagroua no quintal urinando em pé, como era seu hábito na roça, criada que fora apenas pelo pai.

O tormento que o menino Alfeu lhe impunha era como que compensado pela lembrança recorrente do monjolo batendo no Fundão. Mas bom de verdade era sonhar com a mãe. Em imagens, também recorrentes, vê-se ao lado dela ou a brincar com os seixos do riachinho, deixando-se embalar por uma voz feminina figurativizada numa cantiga de ninar. Talvez por isso ficou tão maravilhada ao surpreender a menina Mazília um dia no piano a tocar. A música, mesmo singela, ou talvez por isso mesmo, era um de seus refinamentos genuínos - na banda sonora da fita incluem-se outras cantigas infantis, mas elas não estão diretamente vinculadas às lembranças pregressas da protagonista, ficam por conta do narrador extradiegético.

Quando os primos já não ligavam mais muita importância às suas esquisitices, um acaso veio quebrar a rotina da casa. Conrado, de gênio forte, mas controlado, andava irascível. O motivo não era ignorado: "a farta do jogo", nas palavras de Joviana, a cozinheira. Tendo arrumado uma briga no clube que costumava freqüentar, Conrado de lá se afastara, e agora sentia falta das rodas de jogo com 
os amigos. Nas horas vagas, perambulava pela casa, dividido entre a irritação e o tédio. Constança, com habilidade e sutileza, sugere que o marido passe a trazer os companheiros para jogar em casa, ao que ele acede - e assim foi que, inesperadamente, vislumbrou-se para Biela um pretendente. Perspicaz e atenta, Constança não tardou a perceber que Modesto, filho de um dos parceiros do jogo e ele próprio jogador, parecia interessado pela prima. Verdade é que o rapaz não era lá essas coisas - um tanto esquisito, meio desajeitado, certa fama de espiritado, de vadio -, mas talvez pudesse vir a dar bom noivo, afinal era de muito boa família. Notou, também, que a moça não lhe era indiferente: daí a tramar planos para um possível casório foi, para Constança, uma questão de duas ou três laçadas. Não tardou a convencer o marido de tal possibilidade, o qual em princípio achou a idéia engraçada, senão mesmo absurda; não tardou o pedido formal, feito a Conrado por intermédio do pai do moço. Mais difícil foi convencer Biela, avessa a essa tal história de casamento. Mas Constança tinha lá os seus meios, era competente nessas artes, seria apenas uma questão de tempo, de um ponto a ser bem trabalhado. Tanto teceu que afinal a prima concordou em entrar no jogo: se era do gosto dos primos, então casava. Outra vez os moldes, novamente as agulhas, os bordados, o quarto de costura de novo. Desta feita, costuras para uma boda: enxoval e vestido de noiva.

Não demorou para que a novidade se espalhasse pela cidade, não demorou para que tudo ficasse pronto - só faltava aprontar o noivo, que se embrenhara no sertão para buscar cabeças de gado, a mando do pai. A noiva, pronta, esperava. Ocorre que Modesto.não voltou. Retornaram apenas os dois capatazes que the haviam acompanhado: dele e do gado, nem sinal.

Revoltada, prima Biela agride Constança: Eu não queria mesmo se casar. Foi pra fazer o gosto da prima que eu fiquei noiva.

A câmera, inicialmente em plongée, aproxima-se vagarosamente e enquadra Biela deitada em posição fetal, remoendo em silêncio a desfeita. Num gesto lento, senta-se na cama. No espelho tríplice da penteadeira, contempla-se demoradamente. Engole em seco, a face crispada. Sorri, e do sorriso passa ao riso, depois às 
gargalhadas. Novamente engolindo em seco, começa um pranto silencioso que se transforma em choro convulsivo, ao mesmo tempo em que arrebenta os botões da parte de cima seu traje, arrancandoa. De saia e corpete, violentamente desmancha o coque, liberando os longos cabelos, espalhando-os pelo rosto desfeito em lágrimas. Acalmando-se, passeia as mãos pelo colo, pelos seios, pelos braços nus. Contempla-se outra vez, longamente, agora já sem chorar.

$\mathrm{Na}$ manhã seguinte, Biela apresenta-se frente à prima vestindo os trajes que usava quando chegara do Fundão. Nos ombros, o xale de crochê que fora da mãe. Cumprimenta Constança com voz firme, mirando-a nos olhos. Deixa a sala, dirigindo-se à cozinha. Lá chegando, fala aos empregados, com doçura. Em passos firmes, vai até o pilão. Despe o xale, toma a mão do pilão, e começa.a socar. Com força, decisão.

Biela deixa de freqüentar a mesa da sala de jantar, passando a comer na cozinha com os empregados. Desocupa o quarto da frente, que lhe fora destinado por Constança, mudando-se para um outro, de pequenas dimensões, situado nos fundos do quintal da casa. Começa a movimentar-se sozinha em andanças pela cidade, visitando as casas - à procura não das donas, as senhoras, mas sim das empregadas. Entra pelos fundos, encaminhando-se direto para a área de serviço, para as cozinhas, ao encontro das Marias, das Milurdes, das Jovianas, que passaram a ser as suas amigas. Ajuda a todas elas, colaborando nas lidas de forno e fogão, nos trabalhos de limpeza. Conversa desinibida, sorridente, sem constrangimentos. Gradativamente, passa a assumir, na íntegra, algumas das tarefas domésticas em casas alheias. Prepara biscoitos, balas, quitutes. Começa a receber pequenas pagas pelos serviços prestados. Constança, sabendo, não gosta nada, nada mesmo, aquilo não ficava bem para a família. Reclama para o marido, que concorda: era mesmo uma vergonha.

Conrado chama Biela para um particular e pondera, a prima era rica, não carecia daquilo. Biela, decidida e bem à vontade, replica: não via mal nenhum no que fazia, além de que gostava de dinheiro. $O$ primo insiste, pois, que se era esse o caso, bastava que ela, invés dele, tomasse conta do próprio dinheiro. Não houve conversa: Biela não concorda, dinheiro seu estava bem guardado na mão do primo, 
pessoa de sua confiança. Sucinta e objetiva em seus argumentos, convence Conrado e pronto, assunto encerrado.

Com o tempo, prima Biela passa a guardar sob a cama, armazenadas em jarros de barro, as moedas amealhadas; por vezes, espalha algumas delas sobre a colcha, e brinca - como fazia com os seixos à beira do rio, quando criança.

Numa noite de frio, a caminho de casa, enrolada em xale preto e tossindo muito, Biela percebe estar sendo seguida: na calçada, atrás dela, um vira-lata perdido, sujo e faminto. Acaba adotando o cachorro, o que marca o início de uma grande amizade: os dois se tornam inseparáveis. Uma vez alimentado, banhado e tratado, o animal desconhecido recebe de Biela um nome: Vismundo. Nomeado, Vismundo passa a viver no quarto, na cama de sua, agora, dona - e com ela aprende truques, maneiras, brincadeiras. Assim foram vivendo, ele e Gabriela, Biela pros de casa, até o fim do filme. E o fim colheu prima Biela pouco depois do encontro com Vismundo. Uma doença grave, de pulmão, após ter tomado muita chuva. Médico chamado às pressas; Biela quase desfalecida, com sua camisola branca, é carregada pelo primo para o primeiro quarto que ocupara. $\mathrm{O}$ cachorro fica do lado de fora, a entrada proibida por Constança. A prima perdia-se, mergulhada em febre alta. Em seus instantes derradeiros, Vismundo, onde Vismundo?, ela se ergue da cama, buscando a saída da casa: na mão, um bolinho de milho para o amigo, que gania arranhando a porta, onde, onde Biela?

Na tela, Biela caindo ao chão, lentamente, a queda, Vismundo, o bolinho partido, Vismundo, Biela de novo, as derradeiras imagens, o monjolo batendo, a música da água. $\mathrm{O}$ Fundão.

\section{Percursos e programas}

Temos de reconstituir e balizar, mais ou menos esquematicamente, o percurso de Biela a fim de organizar os nexos dessa já também nossa história, na medida mesmo em que interagimos com ela e selecionamos apenas uma de suas isotopias: as relações entre identidade e alteridade. 
Sob esse ponto de vista, discernimos três momentos ou programas na versão da narrativa apresentada, que se quer fiel, na medida do possível, ao filme. No primeiro, vemos uma Biela que, vinda de fora, do campo, fica perdida no novo mundo em que se imiscui - a casa dos primos, metonímia da cidade. Neste mundo, seu Outro é prima Constança, que lhe passa os parâmetros para ser como eles, os da casa, os da cidade, e está pronta para recebê-la com boa vontade; basta à prima querer, se comportar com convém, vestir-se adequadamente. Biela é levada a querer, seduzida pela beleza e apuro da prima, ademais pronta a admiti-la, a corrigir seus erros, ensiná-la e dar proteção Mas tem muitas dificuldades, ainda sem atinar o porquê, para assimilar os valores que lhe são oferecidos. Procura satisfazer a expectativa de Constança, como se temesse decepcionar os da casa e acabar excluída, mas é difícil sua tarefa. Também não pode se livrar do Fundão, das querenças que traz dentro de si. Não lhe resta outra saída nesta cizânia senão adotar a estratégia de um camaleão ${ }^{8}$, ou seja, tentar parecer com seu outro, o esnobe (papel que cabe como luva a Constança), mas sufocando e, ao mesmo tempo, afirmando em si mesma os valores que trouxe junto à bagagem. A dramaticidade deste conflito atinge seu ápice no episódio da ruptura do noivado, que motiva Biela a renunciar às suas tentativas e esforços para se integrar ao mundo dos primos. Compreendeu, não sem antes ter amargado a humilhação, que não queria, não podia nem sequer sabia ser Constança. Definiu-se, assumiu ser ela mesma.

Inaugura então um segundo programa. Se antes se comportara como camaleão, agora mostra-se $u_{r s} o^{9}$. Com ela, não mais conversas dúbias; não mais fingimentos. Isola-se no quarto dos

8 Para explicar as diferentes trajetorias do que chama figuras sociais, Landowski (2002, pp. 37-39) parte de uma metáfora zoo-social na qual distingue, ao lado das do esnobe e do dândi, as figuras do camaleão e do urso, figuras que, articuladas, compõem os eixos dos contrários e dos subcontrários do quadrado semiótico, respectivamente, tendo como referência uma figura central, caracterizada como a do gentleman, ou senhor "Todo Mundo".

9 Esta nova configuração explica-se bem a partir do que Landowski (2002, p. 50) denomina estratégias do Um e do Outro, nas quais se distinguem as "políticas" do Um (assimilação, exclusão, admissão, segregação) dos "estilos" do Outro (esnobe, dândi, camaleāo, urso); práticas paralelas que podem ser expressas a partir da categoria geral da "junção". 
fundos, não faz mais suas refeições com os familiares, passa a ser, antecipando uma decisão dos primos, um segregado, como o são os empregados dá casa, com os quais se identifica e tem afinidades. O que não quer dizer, absolutamente, que seja uma excluida. Biela, embora pela negação, ainda se referencia na família. Assimilou uma ou outra coisa da prima da qual não pode mais se desvencilhar, como se livrara dos ricos vestidos. Nem se quisesse, por exemplo, poderia voltar ao Fundão. Está só, e se reconhece no seu agora. Anda sozinha pela cidade. Trabalha por gosto, apesar de não dispensar as pagas - gostava das moedas que recebia, brincava com elas, guardava-as. À vontade, de avental e mangas arregaçadas, ri e conversa descontraída com as amigas, suas iguais: cozinheiras, doceiras, arrumadeiras. E pôde sustentar sua posição com facilidade e desenvoltura ao ser questionada pelo primo que, instigado pela mulher, queria colocar fim à sua loucura de andar fazendo serviços domésticos em casas alheias, e, além do mais, receber dinheiro por isso, sendo ela tão rica... Agora, talvez, pudesse dizer com conviç̧ão o que disse certa vez ao ser apresentada pela prima, num encontro casual, ao padre da cidade: "Eu me chamo Gabriela da Conceição Fernandes, Biela pros da casa". Sua casa, porém, já agora era outra e era sua.

Mas há uma falta a ser preenchida que Biela não se havia dado conta: não basta ser ela mesma, é preciso, na condição humana, ser junto. Quem lhe revela isso, paradoxalmente, é Vismundo, um cachorro vira-lata, tão só e tão carente de reconhecimento, de amor, quanto ela. Neste terceiro programa, Biela é para o outro, que lhe devolve o ser, a completude, além do solipsismo em que mergulhara. Por Vismundo ela vive e poderia morrer, e morre conciliada consigo mesma. Conseguiu o que talvez poucos na vida conseguem - firmar o seu desejo. Este o seu segredo?

Ao longo da narrativa fílmica, o percurso da protagonista (situada como Outro) é pontuado pela composição do figurino. A indumentária de Biela, enfaticamente tematizada, compõe as figuras assumidas em suas diferentes trajetórias (a do camaleão quando se identifica com Constança; a do urso, quando se afasta dela), produzindo efeitos de sentido que definem posturas que lhe são 
próprias (em relação ao $U m$, representado por Constançá), além de marcar o lugar por ela ocupado em cada um de seus "estilos".

Assumindo a trajetória do esnobe, Constança, dona de rico e variado guarda-roupa, parece ter saído de um baú de belezuras. Tecidos sedosos misturados a outros, de textura mais pesada, em cores combinadas, tons claros penetrando matizes mais escuros. Padrões lisos, florais, estamparias miúdas; xadrez, petit-pois. Variedade animada, matéria-prima para confecções esmeradas, algumas até bem originais, peculiares; outras, provavelmente, copiadas de modelos franceses, ou neles inspiradas. Vestidos ardilosos, que por meio de cuidadosa e acertada articulação de pregas, cortes e recortes - acentuando uma curva ali, provocando um trejeito acolá - criam formas arredondadas, de uma feminilidade tendendo para o exuberante. Saias cintadas, sobrepostas ou não, abrindo-se em pregas amplas, bem talhadas, cuidadosas em sua tarefa de cobrir/revelar ancas, nesgas de anáguas insistentes, sapatinhos mimosos. Blusas e paletozinhos debruados, mangas trabalhadas, por vezes bicolores, bufantes ou sobrepostas, pequenos botões recobertos de pano. Toilettes primorosas: delicadezas urdidas nos bordados, nos apliques caprichados, nas golas rendadas. Arremates preciosos, precisos. Por cima, sobre os ombros, xales variados: uns rendados, outros em crochê, tramas bem abertas, pontos mais fechados, franjas, triângulos, movimentos. Isso para não falar nos broches, nos brincos, leques, bolsas, sombrinhas de sinhá. Nenhum despojamento, é certo, mas também nenhuma indiscrição, nenhum exagero leviano. Tudo sempre com a devida distinção, tudo sempre no ponto certo, exato, uma roupa para cada ocasião: batas singelas para os interiores domésticos, trajes requintados e completos para a rua, um entremeio desses dois para receber visitas. Capricho, decoro, alinhamento. Elevando ao máximo sua postura esnobe, Constança identifica-se e pode ser vista como $U m$, o parâmetro, um modelo a ser seguido.

Biela, que quando chega à cidade dispõe de um guarda-roupa que cabe numa trouxa, parece ter saído do armário das vassouras. Figura quase andrógena, atenuada por alguma delicadeza de traços no rosto, emoldurado por cabelos apanhados em arranjos sem arte. 
Vestidos simples e escorridos, definindo uma compleição magra e angulosa; caimentos retos, sem recursos artificiosos: busto não delineado, quadris escondidos por cortes retos ou por modelagens frouxas. Trajes de tecidos simples, algodões e chitas. Panos carentes de estamparias, padronagens ou combinações elaboradas. Cores apagadas ou escuras: ocre, azul escuro, tons de cinzas e marrons. Nada de laços, fitas, rendas ou babados. Nenhum adereço, nada que não tenha utilidade prática: saias amplas para movimentos largos, pregas simples. Dois xales apenas: um deles, peça antiga, de crochê, confeccionada em linha amarelo-mostarda, ponto complicado, visivelmente trabalhoso. Herdado da mãe. $O$ outro, também em crochê, preto, ponto simples e trama aberta.

A postura corporal das duas, Biela e Constança, determinada pelo figurino escolhido, é radicalmente oposta: enquanto uma, seja por onde for que estiver circulando, mantém os ombros aprumados, o rosto altivo, os gestos precisos e o andar desenvolto, a outra deixa os ombros parcialmente encurvados, apresentando o rosto quase sempre baixo, o andar desengonçado, por vezes vacilante. Os gestos de Biela - salvo quando se encontra em ambientes como o próprio quarto, a cozinha e o quintal dos fundos - são desajeitados, tímidos e hesitantes.

Na mesma medida em que os tecidos sofisticados que compõem o figurino de Constança conseguem emprestar-lhe uma certa naturalidade elegante ao porte, a simplicidade dos tecidos de fibras naturais - como o algodão e a chita - presentes nas roupas de Biela imprime-lhe um ar de desalento, de pobreza desleixada ${ }^{10}$. As vestes de Constança, bem talhadas, cingidas rentes ao corpo, favorecem posturas corporais da ordem da verticalidade e da firmeza - próprias aos que, ocupando posições centrais, desempenham papéis alinhados com o poder, com a segurança, com a certeza; as de Biela, frouxas e de corte pouco definido, favorecem posturas corporais desaprumadas e vacilantes, condizentes com a dúvida e a não

10 Ėvidentemente, não se pode ignorar que esta é uma questão polêmica, uma vez que a roupa só funciona em situação: ou seja, corpo e roupa atuam em estreita consonância. Aqui mesmo, Biela, na sua fase urso, ainda que trajando as mesmas roupas, apresenta aspecto distinto. 
assertividade características daqueles que, ainda que por escolha própria, não ocupam posições centrais.

A esnobe Constança tende a manter-se sempre a mesma: em qualquer estado de espírito, esteja onde estiver, durante todo o desenrolar do filme sua figura é altiva e elegante no porte - ainda que seja uma altivez tranqüila, sem arrogância ou excessos. Já a camaleoa Biela é mutante, vai sendo tecida, destecida, re-tecida: sua imagem se forma e se transforma na primeira metade da narrativa filmica.

\section{Biela camaleão}

Seduzida pelo fazer persuasivo da prima, Biela tenta mudar e começa pela substituição dos trajes. Embora faça isso com relutância, o que se evidencia em expressões faciais contrafeitas ao provar os vestidos, na rigidez em que caminha quando enverga os novos trajes, repletos de adereços, bem elaborados e confeccionados em panos caros, de boa qualidade: membros rígidos, esticados, pernas e braços abertos além do que seria necessário; passos duros, como se fora um autômato, uma boneca de pau animada, porém parcamente provida de movimentos articulatórios. Muito distintas daquelas a que estava acostumada, as roupas agora são acinturadas, apresentando camadas e superposições; misturam cores e tecidos, laços e babados, tudo isso articulado em composições elaboradas que parecem amarrá-la, tolhendo a expansão corporal, impedido-lhe a espontaneidade do caminhar e dos gestos. A transformação operada no quarto de costura resulta numa espécie de reificação: Biela, portando vestes que não lhe permitem ser nem fazer, parece um objeto. Que não agrada aos outros nem a si própria.

\section{A vez do urso}

O xale de novo, a trouxa outra vez. A sombrinha vermelha. Sem se importar com a opinião alheia, com o seu modo de se dar a ver, Biela recupera as vestes originais com que chegara à cidade. 
Passa a olhar de frente, não mais de soslaio. Os gèstos adquirem firmeza e vigor, anda com mais desenvoltura. Ainda assim, cumpre ressaltar, são gèstos e passos que a personagem desenvólve atuando nos espaços periféricos pelos quais optou: o quarto isolado, localizado na parte dos fundos do terreno na casa dos primos, as áreas de serviço. Dentre os dois xales qué desfila no filme um, recorrente e de elaborada tessitura, chama a atenção: pertencera à mãe perdida nä infância também perdida - e aparéce deslocado para os ombros de Biela; resquício metonímico, herança da mãe, tramas que remetem à Fazenda do Fundão. Retoma todos os seus vestidos escorridos, desprovidos de pregas artificiosas, de recortes insinuantes; as saias amplas e confortáveis, as blusas simples: nada de amarrações elaboradas, de botõezinhos minúsculos enlaçados por alcinhas de pano; nos pés, outra vez as velhas botinas. Cabelos apanhados em tranças singelas, despretensiosas. Significado especial pode ser atribuído à recuperação do xale da mãe - mesmo usado na ocasião em que, ao ser apresentada ao padre da cidade, anunciara-lhe protocolarmente seu nome completo, prenúncio do auto-batismo que só agora, ao final de seu percurso, poderia verdadeiramente enunciar: "Eu merchamo Gabriela da Conceição Fernandes".

\section{Bibliografia}

DOURADO, A. 1996. Uma vida em segredo. Rio de Janeiro: Record. 1976. Uma poética de romance: matéria de carpintaria. Rio de Janeiro: Record.

FLOCH, J-M. 1985. Petites mythologies de l'oeil et de l'esprit. Paris-Amsterdam: Hadès-Benjamins.

FREUD, S. 1976. "O estranho". In: Obras psicológicas completas de Sigmund Freud. Edição Standard Brasileira. Volume. XXVI. Rio de Janeiro: Imago.

GREIMAS, A. J. 2002 . Da imperfeição (Trad. Ana Claúdia de Oliveira). São Paulo: Hacker.

HOUAISS, A. e VILLAR, M. de S. 2001. Dicionário Houaiss da lingua portuguesa. Rio de Janeiro: Objetiva. 
KAUFMANN, P. (ed.) 1996. Dicionário enciclopédico de psicanálise - o legado de Freud e Lacan. Rio de Janeiro: Jorge Zahar.

LACAN, J. 1999. As formações do inconsciente. In: O seminário, Livro 5. Rio de Janeiro: Jorge Zahar.

1998. "Função e campo da fala e da linguagem em psicanálise". In: Escritos. Rio de Janeiro: Jorge Zahar.

1998. "A instância da letra no inconsciente ou a razão desde Freud”. In: Escritos. Rio de Janeiro: Jorge Zahar.

1986. Os escritos técnicos de Freud. In: O seminário, Livro 1. Rio de Janeiro, Jorge Zahar.

LANDOWSKI, E. 1997. "Gosto se discute" in LANDOWSKI, E. e FIORIN, J. L. O gosto da gente, o gosto das coisas. São Paulo: Educ.

. 2002. Presenças do outro. São Paulo: Perspectiva.

OLIVEIRA, A. C. de. 2002. "Por uma semiótica da moda", in CASTILHO, K. e GALVÃO, D. A moda do corpo, o corpo da moda. São Paulo: Esfera. 